FEDERAL RESERVE BANK OF SAN FRANCISCO

WORKING PAPER SERIES

\title{
Loan Officers and Relationship Lending to SMEs
}

\author{
Hirofumi Uchida \\ Wakayama University \\ Gregory F. Udell \\ Indiana University \\ Nobuyoshi Yamori \\ Nagoya University
}

July 2008

Working Paper 2008-17

http://www.frbsf.org/publications/economics/papers/2008/wp08-17bk.pdf

The views in this paper are solely the responsibility of the authors and should not be interpreted as reflecting the views of the Federal Reserve Bank of San Francisco or the Board of Governors of the Federal Reserve System. 


\title{
Loan Officers and Relationship Lending to SMEs ${ }^{\dagger}$
}

\author{
Hirofumi Uchida ${ }^{\ddagger}$ \\ Faculty of Economics \\ uchida@eco.wakayama-u.ac.jp \\ Tel: 81 (73) 457-7710 \\ Gregory F. Udell \\ Kelley School of Business \\ Indiana University \\ gudell@indiana.edu \\ Tel: 1 (812) 855-3394 \\ and \\ Nobuyoshi Yamori \\ Graduate School of Economics \\ Nagoya University \\ yamori@soec.nagoya-u.ac.jp
}

Tel: 81 (52) 789-2361

This version: July 2008

\footnotetext{
${ }^{\dagger}$ This study was conducted as one of the projects of the Regional Finance Workshop of the Research Institute of Economy, Trade, and Industry (RIETI). The authors would like to thank the RIETI for financial support; Masaji Kano, Yoshinori Kon, Emre Ergungor, Makoto Saito, Arito Ono, Makoto Saito, Iichiro Uesugi, Takashi Hatakeda, John Scott, Hideshi Itoh, Yoshio Shimokata, Shin-ichi Hirota, Yasutomo Murasawa, Kamon Iwatsubo, Kazu Hori, Tsutomu Watanabe, Kenya Fujiwara, and Ryuzo Miyao for their helpful comments; and Shuichi Uemura for his administrative help, especially in conducting the RIETI survey. An earlier version of this paper has been presented at the RIETI, Osaka Prefecture University, the Contract Theory Workshop East, the 2006 Fall meeting of the Japanese Economic Association, Kobe University Monetary Economics Seminar, the 2007 FMA meeting, the Hitotsubashi University Macroeconomics and Finance Workshop, Aomori Public Collage, and International Bank and Finance Section seminar at the Federal Reserve Board.

₹ Corresponding author: Faculty of Economics, Wakayama University, 930 Sakaedani, Wakayama, Wakayama 640-8510, Japan. Tel.: 81-73-457-7710, Fax.: 81-73-457-7711, E-mail: uchida@eco.wakayama-u.ac.jp.
} 


\section{Loan Officers and Relationship Lending to SMEs}




\begin{abstract}
Previous research suggests that loan officers play a critical role in relationship lending by producing soft information about SMEs. For the first time, we empirically confirm this hypothesis We also examine whether the role of loan officers differs from small to large banks as predicted by Stein (2002). While we find that small banks produce more soft information, the capacity and manner in which loan officers produce soft information does not seem to differ between large and small banks. This suggests that, although large banks may produce more soft information, they likely tend to concentrate their resources on transactions lending.
\end{abstract}

Keywords: Relationship lending, Small- and medium-sized enterprises, soft information, hierarchical organizations

JEL classification code: G21, L14, D82 


\section{Introduction}

The recent literature on SME financing has emphasized the dichotomy between soft information and hard information. Specifically, this literature has identified soft information with “relationship lending” and hard information with "transactions-based lending” (e.g. Stein 2000 and Berger and Udell 2002). In contrast to hard information, soft information is not easily quantified and consists of information gathered over time through contact with the firm, the firm's management/entrepreneur, the firm's suppliers and customers, and other local sources. Because soft information deteriorates as it is transmitted to others within the hierarchy of the lending institution (e.g., Becker and Murphy 1992, Radner 1993, Bolton and Dewatripont 1994, and Garicano 2000), the role of the loan officer is critical in relationship lending. Banks can avoid diluting soft information by delegating lending authority to the same agent that collects it the loan officer (e.g., Stein 2002, Berger and Udell 2002, Liberati and Mian 2006).

Despite its importance there is relatively little empirical research on the role played by the loan officer in relationship lending. Theory suggests some clear and interesting empirical implications: If the loan officer plays such an important role in relationship lending, then we would expect to see a link between loan officer attributes and loan officer underwriting activities, and the production of soft information. For example, we would expect to see an association between the production of soft information and such things as the frequency of contact between the loan officer and the borrower, and the skill level of the loan officer.

In order to analyze the role of loan officers in relationship lending, we utilize a new and unique data set based on survey data of Japanese SMEs, the Management Survey of Corporate Finance Issues in the Kansai Area. This survey was conducted in Japan in June 2005 and contains data on firms and their loan officers based on a questionnaire sent to SMEs in the Kansai area of Japan. The richness of this data set allows us to overcome a key obstacle in analyzing these issues -- the ability to measure the amount of soft information produced. We do this by 
exploiting questions in the survey that ask the responding firm to rate their main bank on different characteristics of the bank's knowledge of the firm. From this information we construct an index that proxies for the production of soft information.

Using this index, we examine for the first time whether loan officer attributes that proxy for skill (e.g., loan officer turnover, loan officer age) and loan officer lending activities (e.g., frequency of meeting and method of contact) affect the production of soft information. This menu of attributes and activities variables has not been available in prior research. With these variables we can ask how soft information is produced. The results are generally consistent with prior predictions in the literature on the importance of the loan officer. We find that some important loan officer attributes and activities are important in producing soft information about borrowers. Specifically, more soft information tends to be accumulated when loan officer turnover is less and when loan officer contact is frequent.

We also examine whether soft information and the role of loan officers differs from small to large banks as predicted in the theoretical literature on relationship lending (Stein 2002). Consistent with the prior literature we find that small banks produce more soft information (e.g., Scott 2004, Berger et al. 2005). However, we do not find clear evidence that loan officer production of soft information - and by implication, relationship lending -- is limited to small banks. We find that the way that loan officers produce soft information may not be substantially different in large banks than small banks, although large banks tend to do less of it. Thus, if loan officers at large banks were more "active”, they appear to be capable of producing as much soft information as they do at small banks. This suggests the possibility that large banks in Japan may have concentrated their resources in the SME market on transactions lending and not relationship lending.

In short, the unique contribution of our paper is that we analyze the underlying mechanism that drives the production of soft information. Other studies of relationship lending have tended to focus on the association between proxies for relationship strength and borrower benefits 
without consideration of the role of the loan officer and without directly measuring the production of soft information (e.g., Petersen and Rajan 1994, Berger and Udell 1995, Harhoff and Körting 1998). We depart from the conventional approach by directly testing whether loan officer relationship building leads to more production of soft information and whether this process differs between large and small banks.

The remainder of the paper is composed as follows. In the next section, we briefly discuss the related theoretical and empirical literature and we motivate our hypotheses. In section 3 we introduce our data. Section 4 presents our methodology including tests that validate our proxy for information production. Section 5 presents our results. The final section concludes the paper.

\section{Related Literature and Testable Hypotheses}

\subsection{Relationship lending}

Our paper is connected to the growing literature on relationship lending (see for example Boot (2000)). Beginning in the mid-1990s academic research on SME financing began to examine the underwriting process associated with commercial lending. This research explored more precisely how financial institutions extend credit and, more specifically, how they mitigate the informational wedge between themselves and their borrowers by producing information about borrower quality and behaviour. Much of this literature has focused on the related dichotomies between relationship lending vs. transactions-based lending and between soft information vs. hard information (e.g. Rajan 1992, Petersen and Rajan 1995, and Stein 2002). It emphasizes that in contrast to transactions-based lending, relationship lending is particularly well-suited for opaque SMEs that do not have audited financial statements or sufficient pledgeable collateral. ${ }^{1}$

Soft information is acquired "through contact over time with the SME, its owner, and the local community” (Berger and Udell 2006). It can include assessments of a borrower's future

\footnotetext{
1 Subsequent papers have argued that many types of transactions lending may be well-suited to funding opaque SMEs (Berger and Udell 2006, de la Torre, Peria and Schmukler 2008).
} 
prospects culled from contact with borrower's suppliers, customers, competitors, or neighboring businesses (Petersen and Rajan, 1994; Berger and Udell, 1995; Mester et al., 1998; Degryse and van Cayseele, 2000). Ultimately the production soft information benefits borrowers by lowering their fund raising cost and increasing their access to credit.

\subsection{The role of loan officers}

Theory suggests that the production of soft information is generated by the bank loan officer who has the most direct and frequent contact with the borrower (e.g., Berger and Udell 2006). However, it may be quite difficult for the loan officer to communicate this soft information to others in the banking organization without significantly diluting its content (e.g., Stein 2002, Liberti and Mian 2006, and Allessendrini et al. 2008). This implies that the bankborrower relationship in SME lending can be equivalently described as the loan officerentrepreneur relationship (see Berger and Udell 2002). In short, the loan officer plays a key role in both producing soft information and in using it to provide relationship lending. Thus, the capacity of the loan officer to produce soft information will be critical in relationship lending underwriting. This leads to the following testable hypothesis:

\section{Hypothesis 1: The Central Role of the Loan Officer}

The loan officer's capacity to collect soft information about SMEs will materially affect the amount of soft information that is collected. The greater the loan officer's ability, the more soft information he/she will produce. The more activity that a loan officer devotes to collecting soft information, the more soft information he/she will produce.

It also follows from this notion of the primacy of the loan officer that any diversion of lending authority to a higher level in the bank hierarchy risks information dilution and reducing bank-borrower contracting efficiency (e.g., Becker and Murphy 1992, Radner 1993, Bolton and Dewatripont 1994, Garicano 2000, Liberti and Mian 2006, and Allessendrini et al. 2008). Moreover, when the agents who are vested with the responsibility of collecting soft information 
do not make the credit decisions themselves, their incentive to collect this information may be compromised (Aghion and Tirole 1997, Stein 2002). This suggests that larger banking organizations may be ill-equiped to produce soft information and to offer relationship lending to their SME customers (Stein 2002, Berger et al. 2005). As a result, the ability of loan officers at large banks to produce soft information may be largely irrelevant. This leads to a second testable hypothesis:

\section{Hypothesis 2: Loan Officer Production of Soft Information at Large vs. Small Banks}

Large banks will produce less soft information about SMEs than small banks. Furthermore, in contrast to small banks, the loan officer's capacity, and the loan officer's activities, will be unrelated to the production of soft information in large banks.

Our unique data permit us to test both of these hypotheses in the context of the Japanese banking market. The Japanese banking market may be an ideal venue to explore these issues because it is characterized by a variety of lender types: large banks (the city banks), mediumsized banks (the regional banks), and small banks (the Shinkin and cooperative banks).

\subsection{Empirical evidence on the role of loan officers}

Despite the theoretical importance of the loan officer in relationship lending, there has been very little empirical research on the role of loan officers. The empirical literature on relationship lending has tended to emphasize the link between the strength of the bank-borrower relationship and specific benefits such as credit availability and credit terms (e.g., Petersen and Rajan, 1994, 1995; Berger and Udell, 1995; Cole, 1998; Elsas and Krahnen, 1998; Harhoff and Körting 1998). However, these studies have not made a clear distinction between the bank and the loan officer, and do not directly investigate information production and the quality of information (i.e. soft vs. hard).

On the specific topic of soft information production, one study showed that in a large 
multinational bank in Argentina decision-making at the lower level of the bank hierarchy (i.e. closer to loan officers) is likely to be more soft information-intensive (Liberti and Mian 2006). ${ }^{2}$ This would suggest that banks that delegate more authority to their loan officers make more relationship loans and avoid the dilution of soft information by transmitting it through layers of organizational hierarchy. ${ }^{3}$ Another study showed that hard public information may not be used in loan underwriting when banks have a strong relationship with the borrower, and that soft information, if available, is the driving determinant in loan underwriting (García-Appendini 2007). However, these studies do not directly test whether loan officers collect soft information.

There are also a number of studies that indicate that the role of loan officers may be special. Some of these studies focus on aligning the incentives of loans officers with shareholder maximization (Udell 1989, Hertzberg, Liberti, and Paravisini 2007) and others provide indirect evidence that bank mergers may provide incentives for loan officers to take their relationship borrowers to other existing banks or to de novo banks (Berger et al. 1998, Goldberg and White 1998, and DeYoung 1998). The only paper of which we are aware that has directly linked loan officers to soft information production is Scott (2006). Using data on SME lending from a survey of small businesses conducted by the National Federation of Independent Business (NFIB) in the U.S., this paper shows that loan officer turnover was negatively related to credit availability.

\section{Data}

Our analysis utilizes the Management Survey of Corporate Finance Issues in the Kansai Area, which was conducted in June 2005 by the Research Institute of Economy, Trade, and Industry (RIETI). The survey, hereafter the RIETI survey, asks SMEs about firm characteristics,

\footnotetext{
${ }^{2}$ Another study provides indirect evidence on problems associated with transmitting soft information from loan officers to higher levels in the banking organization. This study found that as the distance between branches where loans are originated and the headquarters where lending decisions are made grows, credit availability declines (Alessandrini, Presbitero, Zazzaro 2008).

${ }^{3}$ Empirical evidence suggests that banks in the U.S. differ significantly in terms of the level of loan approval authority they delegate to their loans officers (Udell 1989).
} 
management strategy, bank relationships, the loan screening process, and access to credit. The distribution, collection, and data aggregation of the survey were outsourced to Tokyo Shoko Research (TSR), a credit reporting and information provision company in Japan. Questionnaires were sent out by hard mail to 9,000 firms in three prefectures, Osaka, Hyogo, and Kyoto, in Kansai area in Japan. ${ }^{4}$ These firms were chosen from those in TSR's database. In proportion to the relative size of prefectural product and the number of enterprises in the prefectures, 5,000 firms were chosen from the Osaka prefecture, 2,500 firms were from the Hyogo prefecture, and 1,500 firms were from the Kyoto prefecture. In each prefecture, firms were evenly selected from four employee-size categories, 1) 1 to 20 persons, 2) 21 to 50 persons, 3) 51 to 100 persons, and 4) more than 100 persons. For example, in Osaka prefecture, $1250=5000 / 4$ firms were randomly chosen from firms with 1 to 20 employees.

2041 responses (by hard mail) were received yielding a response rate of $22.7 \%$. The number of effective responses was 2020. We further eliminate firms for which the main bank is not one of seven types. ${ }^{5}$ We further confine our sample firms to small- and medium-sized firms. ${ }^{6}$ The resulting sample consists of 1,500 firms. Panel (C) in Table 1 shows descriptive statistics of the firms in our sample: $12.6 \%$ are in construction, $37.3 \%$ in manufacturing, $20.2 \%$ in wholesale, $4.9 \%$ in retail, $2.1 \%$ in real estate, $1.5 \%$ in restaurants or hotels, $11.2 \%$ in other services and

\footnotetext{
${ }^{4}$ The Kansai area is located in the middle of the main island of Japan, and the three prefectures in the area form the focal point for the economy of western Japan. Osaka is the second largest prefecture in Japan with population of 8,814 (as of October 1, 2004). Its capital, Osaka, is the second biggest business center in Japan. The Osaka prefecture is known to have numerous SMEs. Hyogo prefecture has population of 5,587 (October 1, 2004). The capital city Kobe is well-known as an international port with numerous port-related industries such as steel production and shipbuilding. The population of the Kyoto prefecture is 2,638 (October 1, 2004). Its capital is the historic city of Kyoto. There are a large number of traditional industries in the Kyoto prefecture such as traditional handcrafts and textiles. There are also considerable amounts of high-tech industry located in the Kyoto prefecture.

${ }^{5}$ The included firms had a main bank that was either a city bank, a long-term credit bank, a trust bank, a (first tier) regional bank, a second (tier) regional bank, a Shinkin bank, or a credit cooperative. See below for more details.

${ }^{6}$ In accordance with the Small and Medium Enterprise Basic Law in Japan, SMEs are defined here as enterprises with 300 or fewer regular employees (100 or fewer in Wholesale and Services, 50 or fewer in Retail and Food) or a capital stock of 300 million yen or less (100 million yen or less in Wholesale, 50 million yen or less in Retail, Food and Services).
} 
$10.2 \%$ in information, telecommunications, and transportation. ${ }^{7}$ The average sample firm was 49.5 years old, employs 71 persons, and has a total asset of 2,570 million yen (ASSET).

\title{
4. Variables and Methodology
}

In our analyses we empirically test the two hypotheses in Section 2: the hypothesis that loan officer capacity affects soft information production, and the hypothesis that loan officers produce more soft information in smaller banks. Our analyses will also shed light on a more fundamental question: Is relationship lending an important lending technology in the Japanese bank loan market? If the loan officers produce soft information, then this suggests that relationship is an important component of the financial system landscape in Japan.

\subsection{Hypothesis 1: The Role of Loan Officers}

We examine the first hypothesis, the central role of loan officers in relationship lending, by exploring whether loan officer attributes and activities (i.e., loan officer capacity) affects the production of soft information. Our test takes the following form:

\author{
Production of soft information $=$ \\ f(Loan Officer Attributes/Activities, Relationship Strength, \\ Bank Size Type Dummies, Firm and Entrepreneur \\ Control Variables, Access to Hard Information, \\ Regional and Bank controls)
}

We test Hypothesis 1 by investigating whether the coefficients on our measures of loan officer attributes/activities variables have a significant impact on the production of soft information.

Our dependent variable measures the amount of soft information produced by the bank. By

\footnotetext{
${ }^{7}$ Firms in Agriculture, Fisheries, Electricity, Gas, Finance, Insurance, Medicare, and Education industries were excluded in advance before the questionnaires were sent out.
} 
its nature, soft information is difficult to document and transfer. To overcome this problem we develop a proxy for soft information production in the form of an index based on questions in the RIETI survey that ask the responding firms (i.e., the SME borrowers) to rate how satisfactory their main banks are with respect to different characteristics that likely reflect soft information. The six characteristics refer to: (i) how well the bank knows the firm and its business, (ii) how well the bank knows the firm's managers and owners, (iii) how well the bank knows the firm's industry, (iv) how well the bank knows the local community where the firm is located, (v) how well the bank knows the firm's market, and (vi) the adequacy of the interaction with the loan officer. Firms rated their main bank on a 5-point scale from "very good" to "very bad" on each of these six dimensions.

Using these ratings, we created our proxy for soft information production, SOFT. More specifically, we constructed six categorical variables corresponding to the six characteristics that take on a value from "5” (very much) to “1” (very little). Then we conducted a principal component analysis over these six constructed categorical variables. SOFT is its first principal component. This variable captures $57.8 \%$ of the variance/covariance of the six variables. Summary statistics for SOFT are shown in Panel (A) of Table 1.

The advantage of our soft information measure is that we can directly quantify the amount of soft information that a bank accumulates about each borrower. This, of course, is not a perfect measure because it is based on the borrower's perception and not the bank's. Thus, it has some identifiable shortcomings. First, it might be influenced by subjectivity bias, e.g. it might be influenced by the responding firms' financial condition. Second, it might contain more than just soft information. To account for these biases as much as possible, we use a variety control variables as explained below.

As robustness checks, we used alternative proxies for banks' soft information production. We used alternatively the first five, four, and three characteristics in conducting the principal component analysis. Because the main results were almost the same we do not report these. We 
also calculated an alternative measure that focuses on extreme (i.e. "very much") answers only. That is, we constructed six dummy variables corresponding to the six characteristics above ((i) through (vi)), which take a value of one if the firms responded "very good" to the relevant characteristic, and zero otherwise. The alternative measure, SOFT2, is the first principal component resulting from the principal component analysis over these six "very much" dummies. ${ }^{8}$ Again, most of the main results were the same, so that we report them only when a notable difference is found.

Our key independent variables in equation (1) where we test Hypothesis 1 are the measures that reflect the capacity of loan officers to generate soft information - our loan officer attributes/activities variables. These include three dummy variables directly related to the loan officer him/herself (attributes): NOTURNOVER, which indicates whether there was no turnover of loan officers in the past three years; ${ }^{9}$ NOOFFICER, which indicates whether there is no specific officer at all in the past three years; and, OFFICER20_30 indicating that the loan officer is in his/her 20s or 30s. As an alternative to NOTURNOVER, we also use three dummy variables TURN1, TURN2, and TURN3, which indicate that turnover was respectively one, two, and three or more times in the past three years. Lower loan officer turnover, a specifically assigned loan officer, and an experienced (i.e., older) loan officer should be associated with more soft information production if Hypothesis 1 is true. Hypothesis 1 also suggests that the coefficients on TURN1, TURN2, and TURN3 should all be negative and decreasing in absolute value.

Another set of key variables are those that reflect the activities of loan officers. These variables, which have also been used in other studies (e.g., studies using the U.S. Federal

\footnotetext{
${ }^{8}$ This alternative measure is similar to the soft information index in Scott (2004).

9 It appears to be customary that loan officers in Japanese banks are rotated across branches every two to five years. This rotation system is compliance-driven as prescribed by the Financial Services Agency, the bank regulatory body in Japan. A similar type of policy-induced rotation is found in other countries as well. Hertzberg, Liberti, and Paravisini (2007) report that the length of the loan officerborrower relationship in a large multinational bank in Argentina is less than three years due to rulebased officer turnover. This would bias against finding support for the Hypothesis 1 based on the NOTURNOVER.
} 
Reserve's Survey of Small Business Finance), are the frequency of contact with the bank measured as the average number of contacts (days) per year (FREQUENCY); whether the loan officer typically meets the entrepreneur at his/her place of business (rather than at the bank branch) (MEETPLACE); and, finally, whether contact with the borrower is typically direct rather than by telephone, email or other indirect methods (CONTACTMODE). In addition, we include two variables commonly used in the literature to reflect the strength of the relationship: the length of the main bank relationship (LENGTH) and the distance between the bank and the borrower measured as a dummy variable indicating whether travel time exceeds 30 minutes (DISTANT). ${ }^{10}$ Positive signs for the coefficients of FREQUENCY, MEETPLACE, CONTACTMODE, and LENGTH, and a negative sign for that of DISTANT would be consistent with Hypothesis 1.

Panel (B) of Table 1 shows summary statistics for these variables and Table 2 shows the frequency distribution for selected variables. Possibly the most interesting summary statistic related to our key independent variables is the average length of the bank-borrower relationship: it is quite long -- nearly 27 years. This is much longer than in the U.S., but is comparable to that found using other SME data on Japan (32 years in Uchida, Udell, and Watanabe 2008). It is also interesting to note that while the banking relationship is quite long, officer turnover is relatively frequent. Thus, the loan officer-entrepreneur relationship is quite short. To the extent that the loan officer is paramount in importance with respect to the production of the soft information, this seems to suggest that high loan officer turnover may be an inhibiting factor in the Japanese market. It is also interesting to note that borrower-bank distance appears quite close in Japan (with a mean of 0.165 for DISTANT implying that nearly $85 \%$ of the firms are located within 30 minutes of a main bank branch) and the contact is quite frequent (on average 40 times per year).

We control for a variety of different factors. At the firm level we control for the existence of hard information about the firm in the form of certified audited financial statements (AUDIT).

\footnotetext{
${ }^{10}$ For a more detailed discussion of the research that has utilized these variables see Berger et al. (2005) and Uchida, Udell, and Watanabe (2008).
} 
This may proxy for whether the firm's loans are underwritten on a transactions basis using financial statement lending rather than underwritten on a relationship basis. We also have firm level controls for the firm's asset size (ASSET) and whether the firm is listed on a stock exchange (LISTED). These also likely affect the availability of hard information (other than that reflected by AUDIT) and whether the firm’s loans are transactions based.

Additional firm level controls reflect firm’s financial performance, the firm's industry, the firm's entrepreneur. Some of these variables may be important to control for the subjectivity of the variable SOFT. Because the dependent variable is constructed from a subjective evaluation of the main bank by the firm, it might be biased by the firms' performance. For example, a firm which was denied lending due to its poor performance might devalue the bank's knowledge of the firm. These control variables address this bias. We also control for the firm's bank - specifically the bank's size -- and the firm's region. The labels and definitions for all of these control variables are in the Data Appendix. Descriptive statistics for these variables are shown in Panel (C) of Table $1 .{ }^{11}$

\subsection{Hypothesis 2: Loan Officers, Bank Size and Soft Information Production}

If the Stein (2002) model holds, then we should expect to see that relationship lending is predominantly the domain of small banks. Specifically, we should expect to see that small banks produce more soft information about their customers than large banks and that loan officer attributes and activities are more associated with soft information production at small banks than large banks (Hypothesis 2). We test this hypothesis in a variety of ways.

First, we return to equation (1), but now the focal point becomes the bank size variables -three dummy variables that capture the size differences in the Japanese banking system. The first of these is set to one if the bank is a Shinkin bank or a credit cooperative (UNION). These are the

\footnotetext{
${ }^{11}$ To control for a non-linearity of FIRMAGE, we introduced its squared value. However, it was never significant and caused a serious multicollinearity with FIRMAGE.
} 
smallest banks in Japan. They exclusively target SMEs. The second is set to one if the bank is a regional bank (REGIONAL). These are the mid-sized banks in Japan and their operations tend to be confined to a single prefecture. The third (our default category in equation (1)) is set to one if the bank is a city bank, a long-term credit bank or a trust bank (LARGE). These are the largest banks in Japan. They operate nationwide with a broad business scope. ${ }^{12}$ Our first test simply looks at the coefficients on these bank size dummy variables. A positive sign on UNION and REGIONAL would be consistent with Hypothesis 2. In addition, Hypothesis 2 would suggest that the magnitude of the coefficient would larger for UNION than REGIONAL.

Our second test takes into account that by focusing only on the coefficients on UNION and REGIONAL we are ignoring the effects of all of the other variables in equation (1). For example, we are ignoring the fact that different kinds of SMEs may tend to borrow at different types of banks. Thus, to focus on the issue of whether smaller banks produce more soft information we compare the amount soft information produced by each bank size type. We can do this either by simply comparing the mean level of soft information production (SOFT) for each bank size type or by comparing the level of soft information production (SOFT) for the mean borrower for each bank size type. As with our first test, we would expect that more soft information would be produced by the smaller bank size types for Hypothesis 2, and for the Stein model, to hold.

Hypothesis 2 also suggests that the importance of loan officer capacity should differ across bank size types. Specifically, under Hypothesis 2, at smaller banks we should expect to see that loan officer attributes and activities would be associated with soft information production. However, this would not be the case at larger banks. We can test this by looking at the interactions among the loan officer attributes/activities variables (and the relationship strength variables) and the bank size type dummies (i.e., equation (1) plus the interaction terms). This would take the following form:

\footnotetext{
${ }^{12}$ For a more detailed discussion of these banks see the survey of the Japanese banking system in Uchida and Udell (2008).
} 
The production of soft information $=$

f(Loan Officer Attributes/Activities, Relationship Strength, Bank Size Type Dummies, Loan Officer Attributes/Activities $\times$ Bank Size Type Dummies, Relationship Strength $\times$ Bank Size Type Dummies,

Firm and Entrepreneur Control Variables, Access to Hard Information, Regional and Bank controls)

\title{
4.3 Dependent Variable Validation Tests
}

Our final set of tests focus on validating our dependent variable. If our tests of Hypotheses 1 and 2 are valid, then we must capture soft information production with our dependent variable, SOFT. If SOFT reflects the production of soft information, and if this information is beneficial, then we should observe that borrowers benefit from its production. We test this with the following equation:

\author{
Relationship Benefit = \\ $f$ (Production of soft information, Bank type dummies, \\ Access to hard information, Firm and entrepreneur \\ control variables, Regional and bank controls)
}

We use four alternative proxies to measure relationship benefits. The first two capture the firm's access to credit. The variable, TIGHT, is a dummy variable which equals 1 if the firm answered "hard" to the following question on the RIETI survey: "How did you feel about [how hard it was to obtain] financing in the past year?” We also use the variable, EASY, which is a mirror image of TIGHT, which takes a value of 1 if the firm answered "easy" to the question above. ${ }^{13}$ A third variable, STABLE, is a multi-nomial variable constructed from the firm's rating of the main bank with respect to the stable provision of funds. The respondent firm chooses an

\footnotetext{
${ }^{13}$ The results were unchanged when we used a multi-nomial variable taking a value of 1 (=EASY), -1 (=TIGHT), or 0 (otherwise), and run the regression by ordered logit.
} 
answer on a 5-point scale from 5 (very good) to 1 (very bad). STABLE thus takes a value from one to five. Similar to TIGHT and EASY, STABLE also measures the firm's access to credit. The final alternative benefit variable is INEXPENSIVE, a multi-nomial variable that similarly measures the price of credit, i.e., the provision of inexpensive funds. All four alternative benefit measures are intended to capture the degree of financing constraints experienced by the firm. Summary statistics for these variables are shown in Panel (D) of Table 1.

The key independent variable is our index of soft information production, SOFT, which was used as the dependent variable in equation (1). If SOFT captures soft information production and this is beneficial to borrowers then we would expect that the coefficient on SOFT would be negative for TIGHT, and positive for EASY, STABLE, and INEXPENSIVE. To isolate the effect from SOFT, we use the same control variables as we did in equations 1 and 2.

\section{Results}

\subsection{Hypothesis 1: The Role of Loan Officers}

The results for our test of Hypothesis 1 (i.e., equation (1)), are shown in column (A) of Table $4{ }^{14}$ Regarding the key independent variables that measure loan officer capacity - our attributes, activities and relationship strength variables - we find a significant and positive coefficient on NOTURNOVER and a significant and negative coefficient on NOOFFICER. The former result implies that more information is produced when there is no loan officer turnover and the latter result indicates that less soft information is produced when there is no specific officer. These are consistent with the importance of the loan officer in producing soft information and delivering relationship lending. When we used SOFT2 instead of SOFT (not reported), NOTURNOVER was insignificant suggesting that there may be limits to the production of soft information by loan officers. (Recall that SOFT2 focuses on "particularly good” knowledge.)

\footnotetext{
${ }^{14}$ The number of observation is reduced to 879 because of the unavailability of some control variables. However, the results are qualitatively the same even if we drop all the control variables (the number of observation is 1235).
} 
The results are similar when NOTURNOVER was replaced with TURN1, TURN2, and TURN3 (column (B) of Table 4), i.e., officer turnover has a negative impact on SOFT. Moreover, higher loan officer turnover is associated with a greater negative effect on soft information production. Overall, it thus appears that officer turnover has a serious detrimental effect on the production of soft information.

OFFICER20_30 is positively significant at a 10\% level of significance indicating that younger officers seem to produce more soft information. If a loan officer's age reflects expertise, it does not seem to be important in producing soft information. This finding could be construed as being inconsistent with relationship lending to the extent that the skill level of the officer is important in acquiring soft information.

The results for some of the other key variables tend to be consistent with the hypothesis that loan officers acquire soft information. A positive and strongly significant coefficient on $\log$ (FREQUENCY) implies that the more frequently loan officers and entrepreneurs meet, the more soft information that is produced. ${ }^{15}$ A positive and significant coefficient on CONTACTMODE implies that in-person contact is important in producing soft information.

In contrast, neither DISTANCE nor LENGTH is statistically significant. As for DISTANCE, the insignificance does not stem from its correlation with FREQUENCY because it was insignificant even when we did not use FREQUENCY. This suggests the possibility that FREQUENCY may be a better proxy for officer activity than distance, at least in the Japanese context. As for LENGTH, its lack of significance does not appear to be due to non-linearity: when we added its squared value it was still insignificant. ${ }^{16}$ Nevertheless, the results here are inconsistent with numerous studies that found that a longer and spatially closer relationship enhances relationship lending.

${ }^{15}$ The use of the natural logarighm of FREQUENCY resulted in a better fit than the use of FREQUENCY. Alternatively, an addition of FREQUENCY-squared also resulted in a better fit. However the improvement was smaller than when we used log(FREQUENCY).

${ }^{16}$ Also, when we used $\log (\mathrm{LENGTH})$ instead of LENGTH, the results were unchanged. 
The literature suggests that opaque firms tend to be more dependent on relationship lending. So as a robustness check we split the sample by firm size and firm age, and the existence of audited financial statements (i.e., AUDIT=0). Arguably, smaller firms, younger firms and firms without financial statements are more opaque The results are shown in Table 5. Columns (A) and (B) show the results by firm size (less than vs. more than the median), columns (C) and (D) show the results by firm age (less than vs. more than the median), and column (E) shows the results when we confine the sample firms to those with AUDIT $=0 .{ }^{17}$

Notably, the significance of FREQUENCY is uniform. Irrespective of firm size, firm age, and the existence of audited statements, more soft information is produced by more frequent contact, suggesting that frequent contact may be the single most important factor driving the production of soft information. Also MEETPLACE is significant for smaller firms, CONTACTMODE is significant for smaller firms and older firms, NOTURNOVER is significant for larger firms and older firms, and OFFICER20_30 is significant (but positively) for larger firms and younger firms, implying that the mode of soft information production might be different across firm types. In column (C) LENGTH is significant, implying that a longer relationship is important to accumulate soft information of young firms. Although the results from the split sample are not entirely consistent with Hypothesis 1, the results for firms without an audit (column (E)) - possibly our best measure of opacity -- are consistent with those in Table 4.

On balance, our results are generally (though not entirely) consistent with the hypothesis that loan officers are important in accumulating soft information. Most variables that proxy for officer attributes and activities are significant with the expected signs. In particular, low officer turnover, the existence of a specific loan officer, and frequent officer-entrepreneur contact are important.

\footnotetext{
${ }^{17}$ We additionally run the regression by excluding affiliated firms and keiretsu firms, but the main results were the same as when we used the whole sample.
} 
The lack of significance or unexpected signs of some of the key variables might be attributable to other factors. For example, the insignificance of DISTANT may be due to geographical concentration of banks and firms in Japan. As shown in Table 2, more than $80 \%$ of sample firms are located within 30 minutes from the bank. Our measurement of time distance rather than physical distance may also contribute to the difference from existing studies as well. Also, although the insignificance of LENGTH is inconsistent with earlier studies, it is consistent with recent evidence from Japan using a different data set (Kano, Uchida, Udell, and Watanabe (2006)). Finally, the notable difference between the lack of significance of relationship length in Japan versus other countries may be associated with the fact that banking relationships are strikingly longer in Japan than elsewhere.

\subsection{Hypothesis 2: Loan Officers, Bank Size and Soft Information Production}

Our first test of Hypothesis 2 simply looks at the mean level of soft information production by bank size type. This is shown in the first line of Table 3. Consistent with Hypothesis 2, SOFT is lowest for large banks (-0.2350), next lowest for the regional banks $(0.2998)$ and highest for the smallest banks, Union Banks (0.4484). This indicates that, as predicted by the Stein model, more soft information is produced by smaller banks. This is also consistent with existing empirical evidence (e.g. Berger et al. 2005, and Uchida, Udell, and Watanabe 2008).

It is also interesting to compare the level of the attributes/activities/relationship strength variables by bank type. Consistent with Hypothesis 2 the data show that larger banks are more likely to (i) designate no specific officer (NOOFFICER), (ii) designate younger officers (OFFICER20_30), (iii) be located a greater distance from the firm (DISTANT), and (iv) less frequently visit the firm (FREQUENCY) and (v) have indirect contact (CONTACTMODE), although the differences between regional banks and union banks are not very apparent (Table 3). However, some variables are inconsistent with Hypothesis 2. The means of NOTURNOVER, LENGTH, and MEETPLACE, indicate that large banks may have (slightly) more capacity to 
generate soft information for relationship lending.

However, these are only univariate results. In order to isolate the effects from officer activities and relationship strength and other factors, we turn to a multivariate analysis of Hypothesis 2. We begin by returning to columns (A) and (B) in Table 4 which show our estimations of equation (1). Now, however, we focus on the coefficients on bank size types. Consistent with Hypothesis 2 and the Stein model, the coefficients on REGIONAL (Japanese mid-sized banks) and Union (Japanese small banks) are positive and the coefficient on UNION is larger.

We next look at the amount of soft information produced by the "mean" borrower at each bank. That is, we compare soft information production by different bank size types by calculating the predicted values of SOFT by bank size type based on the regression results from the specification (A) of equation (1) in Table 4. Specifically, we calculate the fitted values of SOFT for an average borrower of each bank type (LARGE=1 (548 firms), REGIONAL=1 (170 firms), and UNION=1 (161 firms)). We calculate the arithmetic averages of all of the independent variables for each bank type, multiply them by the estimated coefficients of the relevant variables, and summed them up. The resulting fitted values represent the level of SOFT when a bank of a respective size type exerts its average level of intensity of officer activities on its average borrower with an average relationship.

The predicted value for SOFT is -0.0209 for LARGE banks, 0.5148 for REGIONAL banks, and 0.4920 for UNION banks. ${ }^{18}$ Again, consistent with Hypothesis 2, we find that large banks produce less soft information. However, inconsistent with our two previous findings (on the bank size type dummies, and on the mean level of soft information production by bank size type), union banks (cooperative banks) appear to produce (slightly) less soft information than regional banks.

Under the previous approach to calculating SOFT for the mean borrower, not only the officer

${ }^{18}$ The relevant value was 0.1766 when we calculate over the whole sample (879 firms). 
attributes/activities and relationship strength variables but also the control variables are averaged by bank size type. Because borrower characteristics are likely to differ by bank type, the differences in the levels of the fitted value might reflect the differences in the borrower characteristics by bank type. It may be more informative to identify the differences in SOFT that solely stem from the difference in the officer attribute/activities and relationship strength by bank type. In other words, we ask which type of bank would produce more soft information for the average borrower (over the whole sample). To do this, we calculate the arithmetic average of the control variables for the whole sample (879 firms) (note that those of the officer/relationship variables are the same as above, i.e. averaged for each bank type). When we use these averages, the predicted values become -0.0711 for LARGE banks, 0.5358 for REGIONAL banks, and 0.6406 for UNION banks. These results are monotonic in bank size and they are consistent with empirical studies such as Berger et al. (2005) and Uchida, Udell, and Watanabe (2008), which show that smaller banks have stronger relationships with borrowers.

Our next set of tests of Hypothesis 2 focus on potential differences in the capacity of loan officers to produce soft information across bank size types. This test involves estimating equation (2) (which adds interaction variables to equation (1)). Hypothesis 2 indicates that loan officer capacity should matter to small banks, but not to large banks. The results are shown in column (C) of Table 4. On balance, the results are inconsistent with Hypothesis 2 and show little difference between large and small banks. Most of the interactions are insignificant with none of the interactions with the smallest banks showing significance with the hypothesized sign.

Overall, our tests of the Hypothesis 2 are mixed. While we do find that smaller banks tend to produce more soft information about their borrowers (consistent with Hypothesis 2), we also find that the capacity for loan officers to produce soft information matters just as much at large banks as small banks (inconsistent with Hypothesis 2).

\subsection{Dependent Variable Validation Tests}


Now we turn to our tests that on the validity of our dependent variable. If our dependent variable, SOFT, indeed captures soft information production and this information is valuable, then it should be reflected in benefits to the borrower as described in equation (3). Regression results for equation (3) are shown in Table 6 (panel A through D). These tables correspond to our alternative measures of relationship benefits: TIGHT (panel A), EASY (panel B), STABLE (panel C), and INEXPENSIVE (panel D). Recall that our key explanatory variable in the regression is SOFT - our proxy for the production of soft information.

Turning to the three measures of relationship benefits that focus on the terms of credit availability - TIGHT, EASY and STABLE - only in the STABLE regression is the coefficient on SOFT statistically significant. That is, only in the STABLE regression do we find that softinformation production benefits borrowers. Turning next to our regression that measures loan price - INEXPENSIVE - SOFT is significant in the predicted direction indicating that information production benefits borrowers. ${ }^{19}$ This is consistent with findings elsewhere that loan rates decline with relationship strength (e.g., Berger and Udell 1995). However, unlike other analysis we use a direct measure of the production of soft information rather than an indirect measure (e.g., the length of the relationship).

To further pursue our investigation of the validity of our dependent variable, we estimated equation 3 by confining the sample to poor-performing firms only. This is because wellperforming firms are not likely to be financially constrained, and soft information production might only improve credit availability for poor-performing firms. Specifically, we identify the firms that lost money in the previous year, and run the regression for those firms only. ${ }^{20}$ The

\footnotetext{
${ }^{19}$ We also run the regressions including the interactions of SOFT with dummies for regional banks and cooperative banks to allow for the possibility that the benefit from soft information production may differ by bank complexity. We found that except for the SOFT*UNION interaction in the TIGHT regression for which sign runs counter to hypothesis 2, there is no difference across bank types in the mechanism through which the production of soft information generates benefits.

${ }^{20}$ In other words, we confine our sample to firms that either lost money last year but made money the year before (i.e., PERFORMANCE_LP=1) or lost money last year and the year before (i.e., PERFORMANCE_LL=1).
} 
results in Table 7 show that now SOFT information does benefit poor performing firms with respect to the two benefit measures TIGHT and EASY. Thus, taken together our validation tests generally provide justification for the use of our measure of soft information production (SOFT).

\section{Conclusion}

Theoretical and empirical work suggests that commercial loan officers play a critical role in relationship lending by producing soft information about their SME borrowers. We test this hypothesis in the context of the Japanese SME loan market. Specifically, we explore whether loan officer attributes and activities are important in producing soft information. On balance, our evidence suggests that officers play an important role in collecting soft information. Frequent officer turnover and the lack of a specifically assigned loan officer result in less soft information production, whereas frequent contact with a borrower contributes to more soft information production. Thus, on balance we find evidence which supports the notion that loan officers are critical to the production of soft information and to the underwriting of relationship lending.

Consistent with the existing empirical work, we find that more soft information is produced by smaller banks. However, in contrast to conventional wisdom, we do not find clear evidence that loan officers at large banks are incapable of producing soft information and potentially underwriting relationship loans. In particular, we find that the same type of loan officer activities and attributes are as associated with soft information production in large banks as in small banks. However, despite this potential, large banks do not appear to engage in as much soft information production or relationship lending as small banks - at least proportionately. This paper thus raises an interesting question for future study: why large banks do not (or cannot) engage in more relationship lending. 


\section{References}

P. Aghion and J. Tirole. Formal and real authority in organizations, Journal of Political Economy 105, 1997.

P. Alessandrini, A. Presbitero and A. Zazzaro, Banks, distances and financing constraints for firms, Review of Finance, forthcoming (2008).

G. Becker and K. Murphy. The division of labor, coordination costs, and knowledge, Quarterly Journal of Economics 107, 1137-1160, 1992.

A.N. Berger, N.H. Miller, M.A. Petersen, R.G. Rajan, and J.C. Stein. Does function follow organizational form? Evidence from the lending practices of large and small banks, Journal of Financial Economics 76, 237-269, 2005.

A.N. Berger, A. Saunders, J.M. Scalise, and G.F. Udell. The effects of bank mergers and acquisitions on small business lending, Journal of Financial Economics 50, 187-229, 1998.

A.N. Berger and G. Udell. Relationship lending and lines of credit in small firm finance, Journal of Business 68, pp. 351-381, 1995.

A.N. Berger and G.F. Udell. Small business credit availability and relationship lending: The importance of bank organizational structure, Economic Journal 112, pp. F32-F53, 2002.

A.N. Berger and G.F. Udell. A more complete conceptual framework for SME finance. Journal of Banking and Finance, forthcoming 2006.

P. Bolton and M. Dewatripont. The firm as a communication network, Quarterly Journal of Economics 109, 809-839, 1994.

A.W.A. Boot. Relationship banking: what do we know? Journal of Financial Intermediation. 9, 7-25, 2000.

R.A. Cole. The importance of relationships to the availability of credit, Journal of Banking and Finance 22, 1998.

H. Degryse and P.V. Cayseele. Relationship lending within a bank-based system: Evidence from European small business data, Journal of Financial Intermediation 9, 90-109, 2000. 
A. de la Torre, M.S. Martinez Peria and S.L. Schmukler. Bank involvement with SMEs: Beyond relationship lending. World Bank working paper, 2008.

R. DeYoung. Comment on Goldberg and White, Journal of Banking and Finance 22, 1998.

R. Elsas and J. Krahnen. Is relationship lending special? Evidence from credit-file data in Germany, Journal of Banking and Finance 22, 1283-1316, 1998.

E. García-Appendini. Soft information in small business lending, EFA 2007 Ljubljana Meetings Paper. (Available at SSRN: http://ssrn.com/abstract=968178 2007), 2007.

L. Garicano. Hierarchies and the organization of knowledge in production, Journal of Political Economy 108, 874-904, 2000

L.G. Goldberg and L.J. White, De novo banks and lending to small businesses, Journal of Banking and Finance 22, 1998.

D. Harhoff and T. Körting. Lending relationships in Germany: Empirical results from survey data, Journal of Banking and Finance 22, 1317-54, 1998.

A. Herzberg, J.M. Liberti, D. Paravisini. Information and incentives inside the firm: Evidence from loan officer rotation, Available at SSRN: http://ssrn.com/abstract=971179, 2007.

M. Kano, H. Uchida, G.F. Udell, and W. Watanabe. Information Verifiability, Bank Organization, Bank Competition and Bank-Borrower Relationships, RIETI discussion paper 06-E-003, the Research Institute of Economy, Trade, and Industry, 2006.

J. Liberti and A. Mian. Estimating the Effect of Hierarchies on Information Use, London Business School working paper, conditionally accepted for Review of Financial Studies, 2006.

L.J. Mester, L.I. Nakamura, and M. Renault. Checking accounts and bank monitoring, Working Paper, Federal Reserve Bank of Philadelphia, 1998.

M.A. Petersen and R.G. Rajan. The benefits of lending relationships: evidence from small business data, Journal of Finance, Vol. 49, pp. 3-37, 1994.

M.A. Petersen and R.G. Rajan. The effect of credit market competition on lending relationships, Quarterly Journal of Economics 110, 407-443, 1995. 
R. Radner. The organization of decentralized information processing, Econometrica 61, 11091146, 1993.

R.G. Rajan. Insiders and outsiders: The choice between informed and arm's-length debt, Journal of Finance 47, 1367-1400, 1992.

J.A. Scott. Small business and the value of community financial institutions, Journal of Financial Services Research 25, 207--230, 2004.

J.A. Scott. Loan officer turnover and credit availability for small firms, Journal of Small Business Management 44, 544-562, 2006.

J.C. Stein. Information production and capital allocation: decentralized versus hierarchical firms, Journal of Finance LVII, 1891-1921, 2002.

T. Takahashi. Loan Screening. (A volume of the New Book Series of the Guidance for Banking Practice). Kinzai, Japan, 2008.

H. Uchida and G. Udell. Banking in Japan, in A. Berger, P. Molyneux, and J. Wilson eds., Oxford Handbook of Banking, Ch. 35, Oxford University Press, forthcoming.

H. Uchida, G. Udell and W. Watanabe. Bank Size and Lending Relationships in Japan, forthcoming in Journal of the Japanese and International Economies, 2008.

G. Udell. Loan quality, commercial loan review and loan officer contracting, Journal of Banking and Finance 13, 367-382, 1989. 


\section{Data Appendix: Definitions of Control Variables}

[Bank size/complexity]

LARGE (dummy: default)

The lending bank is either a city bank, a long-term credit bank, or a trust bank

REGIONAL (dummy)

The lending bank is a regional bank or a second-tier regional bank

UNION (dummy)

The lending bank is a Shinkin bank or a credit cooperative

[Firm's financial number]

ASSET

Firm's asset

[Firm's qualitative performance information]

PERFORMANCE_PP (dummy: default)

Performance of the firm in the past two years (profit followed by a profit)

PERFORMANCE_LP (dummy)

Performance of the firm in the past two years (loss followed by a profit)

PERFORMANCE_PL (dummy)

Performance of the firm in the past two years (profit followed by a loss)

PERFORMANCE_LL (dummy)

Performance of the firm in the past two years (loss followed by a loss)

NODIVIDEND (dummy)

The firm did not pay dividend last year

[Firm's characteristics]

FIRMAGE

Firm's age

(Note: we tried to use the square of FIRMAGE a well, which captures nonlinearity of firm age, but the variable had too high a colleration with FIRMAGE and caused a serious multicollinearity.)

\section{EMPLOYEE}

The number of employee

LISTED (dummy)

The firm is listed

[Entrepreneur's characteristics]

HOMEOWNER (dummy)

The CEO has a house

CEOAGE

The age of the CEO

[Industry dummies]

CONST

Construction

MANUFAC

Manufacturing

WHOLE

Wholesale 
RETAIL

Retail

REALEST

Real estate

RESTAU_HOTEL

Restaurant and Hotel

SERVICES

Services

IT_TRANS (default)

Information and telecommunications, and transportation

[Regional dummies]

OSAKA

Urban Osaka area (the area code of the telephone number is 06) KOBE

Urban Kobe area (the area code of the telephone number is 078)

KYOTO

Urban Kyoto area (the area code of the telephone number is 075)

[Bank competition dummies]

VISITINC_OTHER

Contact increased with other banks

BRANCH

The number of bank branch offices in the city/town/village where the responding firm is located (as of January 31, 2005), divided by the area aggregate $\left(\mathrm{km}^{2}\right.$, as of October 1, 2004) of the city/town/village (Data source: Minryoku data base (Asahi Shinbun Company)). 
Table 1. Descriptive Statistics

This table shows summary statistics of the variables used in our analysis. Panel (A) shows our soft information index SOFT, which is constructed from the respondent firms' ratings about their main banks' knowledge of the firm.

Panel (B) shows our main variables representing attributes/activities of loan officers and those representing the strength of the bank-firm relationships: NOTURNOVER represents the absence of officer turnover, TURN1 through TURN3 respectively represent one, two, or three or more officer turnover. NOOFFICER represents the absence of a specific officer. OFFICER20_30 represents that the officer is in his/her 20s or 30s. LENGTH represents the year of the bank-borrower relationship. DISTANT represents that it takes more than 30 minutes from the firm to the bank branch. FREQUENCY represents the average number of firm-bank contact per year. MEETPLACE represents that the officer-firm contact usually takes place at the firm. CONTACTMODE represents that in-person contact is usually used. More detailed description is found in section 4.1 under the heading "Key Independent Variables." More information about some of these variables are also found in Table 2.

Panel (C) shows our control variables, of which definitions are described in the Data Appendix.

Panel (D) shows the variables representing benefits from bank-borrower relationships. TIGHT (EASY) means that the financial condition of the firm in the past one year was tight (easy). STABLE and INEXPENSIVE respectively represents the firms' evaluation of the main bank in terms of stable and inexpensive provision of funds. More detailed description is in section 4.2 under the heading "Dependent Variables."

\begin{tabular}{|c|c|c|c|c|c|}
\hline & $\mathrm{N}$ & Mean & Std. Dev. & Min. & Max. \\
\hline \multicolumn{6}{|c|}{ (A) Soft information index } \\
\hline SOFT & 1364 & 0.000 & 1.863 & -7.415 & 4.156 \\
\hline \multicolumn{6}{|c|}{ (B) Officer attributes/capacity and relationship strength } \\
\hline NOTURNOVER $(=0,1)$ & 1474 & 0.071 & (NA) & 0 & 1 \\
\hline TURN1 $(=0,1)$ & 1474 & 0.328 & (NA) & 0 & 1 \\
\hline TURN2 $(=0,1)$ & 1474 & 0.307 & (NA) & 0 & 1 \\
\hline TURN3 $(=0,1)$ & 1474 & 0.256 & (NA) & 0 & 1 \\
\hline NOOFFICER $(=0,1)$ & 1474 & 0.036 & (NA) & 0 & 1 \\
\hline OFFICER20_30 $(=0,1)$ & 1430 & 0.708 & (NA) & 0 & 1 \\
\hline LENGTH (year) & 1417 & 26.634 & 15.9656 & 0 & 109 \\
\hline DISTANT $(=0,1)$ & 1493 & 0.165 & (NA) & 0 & 1 \\
\hline FREQUENCY (days) & 1407 & 40.169 & 59.851 & 1 & 365 \\
\hline MEETPLACE $(=0,1)$ & 1447 & 0.770 & (NA) & 0 & 1 \\
\hline CONTACTMODE $(=0,1)$ & 1457 & 0.554 & (NA) & 0 & 1 \\
\hline \multicolumn{6}{|c|}{ (C) Control variables } \\
\hline LARGE $(=0,1)$ & 1500 & 0.619 & (NA) & 0 & 1 \\
\hline REGIONAL $(=0,1)$ & 1500 & 0.195 & (NA) & 0 & 1 \\
\hline $\operatorname{UNION}(=0,1)$ & 1500 & 0.185 & (NA) & 0 & 1 \\
\hline AUDIT $(=0,1)$ & 1457 & 0.119 & (NA) & 0 & 1 \\
\hline ASSET (million yen) & 1366 & $2,570.00$ & $4,500.00$ & 5.00 & $56,900.00$ \\
\hline PERFORMANCE_PP $(=0,1)$ & 1468 & 0.747 & (NA) & 0 & 1 \\
\hline PERFORMANCE_LP $(=0,1)$ & 1468 & 0.105 & (NA) & 0 & 1 \\
\hline PERFORMANCE_PL $(=0,1)$ & 1468 & 0.080 & (NA) & 0 & 1 \\
\hline PERFORMANCE_LL $(=0,1)$ & 1468 & 0.068 & (NA) & 0 & 1 \\
\hline DIVIDEND $(=0,1)$ & 1455 & 0.414 & (NA) & 0 & 1 \\
\hline FIRMAGE (year) & 1356 & 49.458 & 24.117 & 1 & 137 \\
\hline EMPLOYEE (person) & 1500 & 71.261 & 84.110 & 1 & 1172 \\
\hline LISTED $(=0,1)$ & 1453 & 0.009 & (NA) & 0 & 1 \\
\hline HOMEOWNER $(=0,1)$ & 1294 & 0.946 & (NA) & 0 & 1 \\
\hline CEOAGE (year) & 1433 & 60.354 & 9.745 & 27 & 94 \\
\hline OSAKA $(=0,1)$ & 1500 & 0.416 & (NA) & 0 & 1 \\
\hline $\operatorname{KOBE}(=0,1)$ & 1500 & 0.100 & (NA) & 0 & 1 \\
\hline KYOTO $(=0,1)$ & 1500 & 0.139 & (NA) & 0 & 1 \\
\hline CONST $(=0,1)$ & 1500 & 0.126 & (NA) & 0 & 1 \\
\hline MANUFAC $(=0,1)$ & 1500 & 0.373 & (NA) & 0 & 1 \\
\hline WHOLE $(=0,1)$ & 1500 & 0.202 & (NA) & 0 & 1 \\
\hline RETAIL $(=0,1)$ & 1500 & 0.049 & (NA) & 0 & 1 \\
\hline REALEST $(=0,1)$ & 1500 & 0.021 & (NA) & 0 & 1 \\
\hline RESTAU_HOTEL $(=0,1)$ & 1500 & 0.015 & (NA) & 0 & 1 \\
\hline SERVICES $(=0,1)$ & 1500 & 0.112 & (NA) & 0 & 1 \\
\hline IT_TRANS $(=0,1)$ & 1500 & 0.102 & (NA) & 0 & 1 \\
\hline VISITINC_OTHER $(=0,1)$ & 1459 & 0.587 & (NA) & 0 & 1 \\
\hline BRANCH & 1500 & 2.852 & 4.152 & 0 & 15.653 \\
\hline \multicolumn{6}{|c|}{ (D) Benefit from relationship } \\
\hline TIGHT $(=0,1)$ & 1470 & 0.227 & (NA) & 0 & 1 \\
\hline $\operatorname{EASY}(=0,1)$ & 1470 & 0.397 & (NA) & 0 & 1 \\
\hline STABLE & 1383 & 3.842 & (NA) & 1 & 5 \\
\hline INEXPENSIVE & 1383 & 3.394 & (NA) & 1 & 5 \\
\hline
\end{tabular}




\section{Table 2. Frequency Distribution of Loan Officer Attributes/Activities and Relationship Strength}

This table presents detailed description of the loan officer attributes, capacity, and the offficer contact with the borrower. Officer turnover represents how many times the responding firm experienced a change of the assigned loan officer in the past three years. Officer age represents the age of the current officer. Time distance represents the time it takes from the firm to the bank branch. Meet place represents where the firm and the officer usually have a contact. Mode of contact represents the method usually used when they have contact.

\begin{tabular}{|c|c|c|c|}
\hline & Options & Frequency & $\%$ \\
\hline \multirow[t]{6}{*}{ Officer turnover } & No turnover & 105 & $7 \%$ \\
\hline & Once & 484 & $33 \%$ \\
\hline & Twice & 453 & $31 \%$ \\
\hline & Three times or more & 378 & $26 \%$ \\
\hline & No officer & 53 & $4 \%$ \\
\hline & Total & 1473 & $100 \%$ \\
\hline \multirow[t]{6}{*}{ Officer age } & $20 \mathrm{~s}$ & 116 & $8 \%$ \\
\hline & $30 \mathrm{~s}$ & 896 & $63 \%$ \\
\hline & $40 \mathrm{~s}$ & 371 & $26 \%$ \\
\hline & $50 \mathrm{~s}$ & 45 & $3 \%$ \\
\hline & $60 \mathrm{~s}$ & 1 & $0 \%$ \\
\hline & Total & 1429 & $100 \%$ \\
\hline \multirow{6}{*}{$\begin{array}{l}\text { Time distance } \\
\text { (minutes) }\end{array}$} & 10 or less & 590 & $40 \%$ \\
\hline & 30 or less & 654 & $44 \%$ \\
\hline & 60 or less & 207 & $14 \%$ \\
\hline & 120 or less & 31 & $2 \%$ \\
\hline & over 120 & 8 & $1 \%$ \\
\hline & Total & 1490 & $100 \%$ \\
\hline \multirow[t]{4}{*}{ Meet place } & At the company & 1114 & $77 \%$ \\
\hline & At bank branch & 300 & $21 \%$ \\
\hline & Other & 28 & $2 \%$ \\
\hline & Total & 1442 & $100 \%$ \\
\hline \multirow[t]{6}{*}{ Mode of contact } & In person & 807 & $55 \%$ \\
\hline & Tel or fax & 612 & $42 \%$ \\
\hline & E-mail & 14 & $1 \%$ \\
\hline & IT tool (other than e-mail) & 13 & $1 \%$ \\
\hline & Other & 11 & $1 \%$ \\
\hline & Total & 1457 & $100 \%$ \\
\hline
\end{tabular}


Table 3. Soft Information, Officer Attributes/Activities, and Relationship Strength by Bank Type

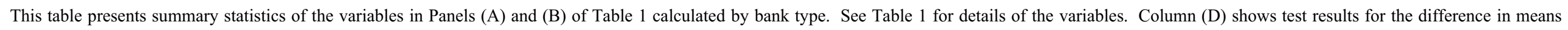
across different bank types. In this column, ***,**, and * indicate that the null hypothesis of the relevant means being the same is rejected at a $1 \%, 5 \%$, and $10 \%$ level of significance.

\begin{tabular}{|c|c|c|c|c|c|c|c|c|c|c|c|c|c|c|c|c|c|c|}
\hline & \multicolumn{5}{|c|}{ (A) Large banks } & \multicolumn{5}{|c|}{ (B) Regional banks } & \multicolumn{5}{|c|}{ (C) Union banks } & \multicolumn{3}{|c|}{ (D) Difference in means tests } \\
\hline & $\mathrm{N}$ & Mean & Std.Dev. & Min. & Max & $\mathrm{N}$ & Mean & Std.Dev. & Min. & Max & $\mathrm{N}$ & Mean & Std.Dev. & Min. & Max & $\begin{array}{l}\text { Large vs. } \\
\text { Regional } \\
\end{array}$ & $\begin{array}{c}\text { Large vs. } \\
\text { Union }\end{array}$ & $\begin{array}{l}\text { Regional } \\
\text { vs. Union }\end{array}$ \\
\hline SOFT & 840 & -0.2350 & 1.8346 & -7.4153 & 4.1525 & 262 & 0.2998 & 1.8793 & -6.5940 & 4.1557 & 262 & 0.4484 & 1.8150 & -6.4993 & 4.1557 & $* * *$ & $* * *$ & \\
\hline NOTURNOVER $(=0,1)$ & 913 & 0.0767 & (NA) & 0 & 1 & 289 & 0.0727 & (NA) & 0 & 1 & 272 & 0.0515 & (NA) & 0 & 1 & & & \\
\hline TURN1 $(=0,1)$ & 913 & 0.2892 & (NA) & 0 & 1 & 289 & 0.3633 & (NA) & 0 & 1 & 272 & 0.4228 & (NA) & 0 & 1 & $* *$ & $* * *$ & \\
\hline TURN2 $(=0,1)$ & 913 & 0.3067 & (NA) & 0 & 1 & 289 & 0.3183 & (NA) & 0 & 1 & 272 & 0.2978 & (NA) & 0 & 1 & & & \\
\hline TURN3 $(=0,1)$ & 913 & 0.2826 & (NA) & 0 & 1 & 289 & 0.2145 & (NA) & 0 & 1 & 272 & 0.2132 & (NA) & 0 & 1 & $* *$ & $* *$ & \\
\hline NOOFFICER $(=0,1)$ & 913 & 0.0449 & (NA) & 0 & 1 & 289 & 0.0311 & (NA) & 0 & 1 & 272 & 0.0110 & $(\mathrm{NA})$ & 0 & 1 & & $* * *$ & \\
\hline OFFICER20 $30(=0,1)$ & 874 & 0.8055 & (NA) & 0 & 1 & 284 & 0.5704 & (NA) & 0 & 1 & 272 & 0.5368 & (NA) & 0 & 1 & $* * *$ & $* * *$ & \\
\hline LENGTH (year) & 873 & 28.3184 & 16.9968 & 1 & 109 & 281 & 24.1566 & 13.6974 & 0 & 80 & 263 & 23.6920 & 13.8161 & 1 & 60 & $* * *$ & $* * *$ & \\
\hline DISTANT $(=0,1)$ & 925 & 0.1957 & (NA) & 0 & 1 & 291 & 0.0859 & (NA) & 0 & 1 & 277 & 0.1444 & (NA) & 0 & 1 & $* * *$ & $*$ & $* *$ \\
\hline FREQUENCY (days) & 857 & 28.0168 & 39.2178 & 1 & 365 & 277 & 60.7289 & 79.8620 & 1 & 365 & 273 & 57.4543 & 77.5186 & 1 & 365 & $* * *$ & $* * *$ & \\
\hline MEETPLACE $(=0,1)$ & 889 & 0.8020 & (NA) & 0 & 1 & 284 & 0.7430 & (NA) & 0 & 1 & 274 & 0.6934 & (NA) & 0 & 1 & $* *$ & $* * *$ & \\
\hline CONTACTMODE $(=0,1)$ & 900 & 0.4978 & (NA) & 0 & 1 & 284 & 0.6585 & (NA) & 0 & 1 & 273 & 0.6300 & (NA) & 0 & 1 & $* * *$ & $* * *$ & \\
\hline
\end{tabular}


Table 4. Soft Information Production

(The accumulation of soft information $)=f($ Loan officer attributes/capacity, Relationship strength, Bank type dummies, Firm and entrepreneur control variables, Access to hard information, Regional and bank controls).

This table shows the OLS estimation results for the determination of soft information production. The dependent variable is a proxy for soft information accumulation, SOFT. The main independent variables are those described in Panel (B) of Table 1, which represent attributes/capacity of loan officers and the strength of the bank-firm relationships. ***, **, or * means that the coefficient is statistically significant at a $1 \%, 5 \%$, or $10 \%$ level. Robust Huber/White/sandwich estimator of variances are shown, because the White test rejected the null hypothesis of no heteroskedasticity at a 5 percent level of significance.

\begin{tabular}{|c|c|c|c|c|c|c|c|c|c|c|c|c|c|c|}
\hline \multirow{2}{*}{\multicolumn{3}{|c|}{ Variable }} & \multicolumn{4}{|c|}{ (A) } & \multicolumn{4}{|c|}{ (B) } & \multicolumn{4}{|c|}{ (C) } \\
\hline & & & Coefficient & & Std. Error & Prob. & Coefficient & & Std. Error & Prob. & Coefficient & & Std. Error & Prob. \\
\hline \multicolumn{2}{|c|}{ Intercept } & & -7.4339 & $* * *$ & 1.2179 & 0.000 & -6.8061 & $* * *$ & 1.2148 & 0.000 & -7.2115 & $* * *$ & 1.2687 & 0.000 \\
\hline \multirow{27}{*}{$\begin{array}{l}\text { Loan officer } \\
\text { attributes/activities } \\
\text { and } \\
\text { Relationship strength }\end{array}$} & NOTURNOVER & & 0.4402 & $* *$ & 0.1867 & 0.019 & & & & & 0.2328 & & 0.2278 & 0.307 \\
\hline & TURN1 & & & & & & -0.2160 & & 0.1961 & 0.271 & & & & \\
\hline & TURN2 & & & & & & -0.5291 & $* * *$ & 0.1993 & 0.008 & & & & \\
\hline & TURN3 & & & & & & -0.6638 & $* * *$ & 0.2102 & 0.002 & & & & \\
\hline & NOOFFICER & & -1.8029 & $* * *$ & 0.3905 & 0.000 & -2.2392 & $* * *$ & 0.4103 & 0.000 & -1.6352 & $* * *$ & 0.3665 & 0.000 \\
\hline & OFFICER20_30 & & 0.2429 & $*$ & 0.1330 & 0.068 & 0.2555 & $*$ & 0.1325 & 0.054 & 0.0170 & & 0.1865 & 0.927 \\
\hline & LENGTH & & 0.0000 & & 0.0037 & 0.991 & -0.0007 & & 0.0037 & 0.853 & -0.0005 & & 0.0042 & 0.909 \\
\hline & DISTANT & & 0.1059 & & 0.1532 & 0.489 & 0.1211 & & 0.1537 & 0.431 & 0.1009 & & 0.1690 & 0.550 \\
\hline & $\log ($ FREQUENCY) & & 0.4481 & $* * *$ & 0.0620 & 0.000 & 0.4566 & $* * *$ & 0.0624 & 0.000 & 0.5909 & $* * *$ & 0.0787 & 0.000 \\
\hline & MEETPLACE & & 0.2190 & & 0.1407 & 0.120 & 0.2032 & & 0.1397 & 0.146 & 0.3940 & $* *$ & 0.2005 & 0.050 \\
\hline & CONTACTMODE & & 0.2140 & $*$ & 0.1106 & 0.053 & 0.2003 & $*$ & 0.1105 & 0.070 & 0.0815 & & 0.1310 & 0.534 \\
\hline & NOTURNOVER & *REGIONAL & & & & & & & & & 0.4025 & & 0.5129 & 0.433 \\
\hline & NOOFFICER & *REGIONAL & & & & & & & & & -0.4983 & & 0.6580 & 0.449 \\
\hline & OFFICER20_30 & *REGIONAL & & & & & & & & & 0.0660 & & 0.3425 & 0.847 \\
\hline & LENGTH & *REGIONAL & & & & & & & & & -0.0088 & & 0.0109 & 0.421 \\
\hline & DISTANT & *REGIONAL & & & & & & & & & -0.2480 & & 0.4044 & 0.540 \\
\hline & $\log ($ FREQUENCY) & *REGIONAL & & & & & & & & & -0.1014 & & 0.1607 & 0.528 \\
\hline & MEETPLACE & *REGIONAL & & & & & & & & & -0.3863 & & 0.3640 & 0.289 \\
\hline & CONTACTMODE & *REGIONAL & & & & & & & & & 0.6417 & $* *$ & 0.3232 & 0.047 \\
\hline & NOTURNOVER & *UNION & & & & & & & & & 0.3099 & & 0.6274 & 0.621 \\
\hline & NOOFFICER & *UNION & & & & & & & & & (NA) & & & \\
\hline & OFFICER20_30 & *UNION & & & & & & & & & 0.6756 & $* *$ & 0.3202 & 0.035 \\
\hline & LENGTH & *UNION & & & & & & & & & 0.0139 & & 0.0089 & 0.119 \\
\hline & DISTANT & *UNION & & & & & & & & & 0.3056 & & 0.5525 & 0.580 \\
\hline & $\log$ (FREQUENCY) & *UNION & & & & & & & & & -0.4084 & $* * *$ & 0.1445 & 0.005 \\
\hline & MEETPLACE & *UNION & & & & & & & & & -0.0741 & & 0.3656 & 0.840 \\
\hline & CONTACTMODE & *UNION & & & & & & & & & 0.2537 & & 0.3200 & 0.428 \\
\hline \multirow[t]{2}{*}{ Bank type dummies } & REGIONAL & & 0.3898 & $* *$ & 0.1702 & 0.022 & 0.3438 & $* *$ & 0.1702 & 0.044 & 0.6339 & & 0.7640 & 0.407 \\
\hline & UNION & & 0.5779 & $* * *$ & 0.1691 & 0.001 & 0.5232 & $* * *$ & 0.1658 & 0.002 & 0.9641 & & 0.5930 & 0.104 \\
\hline Access to hard info & AUDIT & & -0.1227 & & 0.1837 & 0.504 & -0.1231 & & 0.1816 & 0.498 & -0.1523 & & 0.1850 & 0.411 \\
\hline \multirow{20}{*}{$\begin{array}{l}\text { Firm and } \\
\text { entrepreneur control } \\
\text { variables }\end{array}$} & LOG(ASSET) & & 0.2789 & $* * *$ & 0.0637 & 0.000 & 0.2674 & $* * *$ & 0.0630 & 0.000 & 0.2628 & $* * *$ & 0.0654 & 0.000 \\
\hline & PERFORMANCE_LP & & 0.0265 & & 0.1849 & 0.886 & 0.0319 & & 0.1839 & 0.862 & 0.0475 & & 0.1885 & 0.801 \\
\hline & PERFORMANCE_PL & & -0.4820 & $*$ & 0.2529 & 0.057 & -0.4612 & $*$ & 0.2492 & 0.065 & -0.4360 & $*$ & 0.2411 & 0.071 \\
\hline & PERFORMANCE_LL & & 0.7600 & $* * *$ & 0.2300 & 0.001 & 0.7417 & $* * *$ & 0.2314 & 0.001 & 0.7358 & $* * *$ & 0.2339 & 0.002 \\
\hline & NODIVIDEND & & -0.3308 & $* * *$ & 0.1234 & 0.008 & -0.3350 & $* * *$ & 0.1223 & 0.006 & -0.3232 & $* * *$ & 0.1229 & 0.009 \\
\hline & FIRMAGE & & 0.0011 & & 0.0027 & 0.674 & 0.0013 & & 0.0027 & 0.638 & 0.0013 & & 0.0027 & 0.633 \\
\hline & LOG(EMPLOYEE) & & 0.0638 & & 0.0807 & 0.430 & 0.0621 & & 0.0807 & 0.442 & 0.0438 & & 0.0835 & 0.600 \\
\hline & LISTED & & -0.2978 & & 0.3504 & 0.396 & -0.2567 & & 0.3723 & 0.491 & -0.3952 & & 0.3512 & 0.261 \\
\hline & HOMEOWNER & & -0.0730 & & 0.2443 & 0.765 & -0.0892 & & 0.2476 & 0.719 & -0.1395 & & 0.2485 & 0.575 \\
\hline & CEOAGE & & -0.0028 & & 0.0060 & 0.642 & -0.0020 & & 0.0059 & 0.743 & -0.0041 & & 0.0060 & 0.495 \\
\hline & OSAKA & & -0.0589 & & 0.1477 & 0.690 & -0.0347 & & 0.1467 & 0.813 & -0.0714 & & 0.1477 & 0.629 \\
\hline & KOBE & & -0.2401 & & 0.2062 & 0.245 & -0.1610 & & 0.2075 & 0.438 & -0.1804 & & 0.2031 & 0.375 \\
\hline & KYOTO & & 0.1156 & & 0.1783 & 0.517 & 0.1289 & & 0.1775 & 0.468 & 0.2082 & & 0.1846 & 0.260 \\
\hline & CONST & & -0.4225 & $*$ & 0.2366 & 0.075 & -0.3998 & $*$ & 0.2330 & 0.087 & -0.3984 & $*$ & 0.2377 & 0.094 \\
\hline & MANUFAC & & -0.4158 & $* *$ & 0.2034 & 0.041 & -0.3987 & $* *$ & 0.1998 & 0.046 & -0.3805 & $*$ & 0.2020 & 0.060 \\
\hline & WHOLE & & -0.4236 & $*$ & 0.2239 & 0.059 & -0.3995 & $*$ & 0.2221 & 0.072 & -0.4344 & $* *$ & 0.2206 & 0.049 \\
\hline & RETAIL & & -0.6176 & & 0.4026 & 0.125 & -0.5402 & & 0.4032 & 0.181 & -0.5578 & & 0.3946 & 0.158 \\
\hline & REALEST & & 0.5463 & & 0.4543 & 0.229 & 0.5603 & & 0.4383 & 0.202 & 0.6046 & & 0.4264 & 0.157 \\
\hline & RESTAU_HOTEL & & -0.3362 & & 0.5163 & 0.515 & -0.3840 & & 0.5027 & 0.445 & -0.2834 & & 0.5319 & 0.594 \\
\hline & SERVICES & & -0.2237 & & 0.2509 & 0.373 & -0.1763 & & 0.2473 & 0.476 & -0.1863 & & 0.2588 & 0.472 \\
\hline \multirow{3}{*}{$\begin{array}{l}\text { Regional and bank } \\
\text { controls }\end{array}$} & VISITINC_OTHER & & 0.1124 & & 0.1110 & 0.312 & 0.1110 & & 0.1107 & 0.316 & 0.1133 & & 0.1138 & 0.320 \\
\hline & BRANCHR & & 0.0144 & & 0.0147 & 0.327 & 0.0149 & & 0.0146 & 0.310 & 0.0206 & & 0.0151 & 0.172 \\
\hline & $\begin{array}{l}\text { nber of observations } \\
\text { R-squared }\end{array}$ & & $\begin{array}{r}879 \\
0.215\end{array}$ & & & & $\begin{array}{r}879 \\
0.226\end{array}$ & & & & $\begin{array}{r}879 \\
0.239\end{array}$ & & & \\
\hline
\end{tabular}




\section{Table 5. Soft Information Production for Split Sample (Excerpts)}

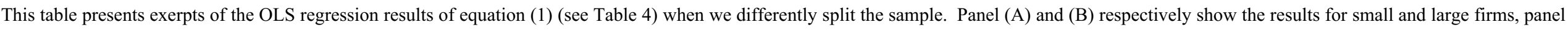

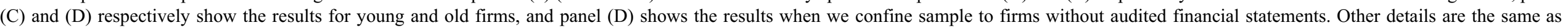

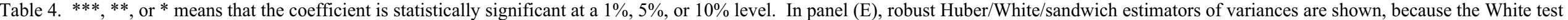
rejected the null hypothesis of no heteroskedasticity at a 5 percent level of significance.

\begin{tabular}{|c|c|c|c|c|c|c|c|c|c|c|c|c|c|c|c|c|c|c|c|c|}
\hline \multirow[b]{2}{*}{ Variable } & \multicolumn{4}{|c|}{ (A) Small firms } & \multicolumn{4}{|c|}{ (B) Large firms } & \multicolumn{4}{|c|}{ (C) Young firms } & \multicolumn{4}{|c|}{ (D) Old firms } & \multicolumn{4}{|c|}{ (E) $\mathrm{AUDIT}=0$} \\
\hline & Coefficient & & Std. Error & Prob. & Coefficient & & Std. Error & Prob. & Coefficient & & Std. Error & Prob. & Coefficient & & Std. Error & Prob. & Coefficient & & Std. Error & Prob. \\
\hline NOTURNOVER & 0.3333 & & 0.3323 & 0.316 & 0.5727 & $* *$ & 0.2792 & 0.041 & 0.2071 & & 0.3007 & 0.491 & 0.5958 & * & 0.3067 & 0.053 & 0.4058 & $* *$ & 0.1926 & 0.035 \\
\hline NOOFFICER & -1.8072 & & 1.2218 & 0.140 & -1.3384 & & 1.5429 & 0.386 & -2.2518 & & 1.6811 & 0.181 & -1.4951 & & 1.1112 & 0.179 & -2.2543 & $* * *$ & 0.2985 & 0.000 \\
\hline LENGTH & 0.0033 & & 0.0062 & 0.591 & -0.0021 & & 0.0051 & 0.672 & 0.0200 & $* * *$ & 0.0076 & 0.009 & -0.0034 & & 0.0049 & 0.487 & -0.0005 & & 0.0039 & 0.903 \\
\hline DISTANT & 0.4132 & & 0.2593 & 0.112 & -0.1224 & & 0.1864 & 0.512 & -0.0777 & & 0.2226 & 0.727 & 0.1976 & & 0.2142 & 0.357 & 0.1078 & & 0.1662 & 0.517 \\
\hline $\log$ (FREQUENCY) & 0.5058 & $* * *$ & 0.0797 & 0.000 & 0.3627 & $* * *$ & 0.0785 & 0.000 & 0.4427 & $* * *$ & 0.0793 & 0.000 & 0.4511 & $* * *$ & 0.0785 & 0.000 & 0.4471 & $* * *$ & 0.0661 & 0.000 \\
\hline MEETPLACE & 0.4024 & $* *$ & 0.2008 & 0.046 & 0.0021 & & 0.1977 & 0.991 & 0.1223 & & 0.1977 & 0.537 & 0.2921 & & 0.1940 & 0.133 & 0.2512 & $*$ & 0.1466 & 0.087 \\
\hline Number of & 439 & & & & 440 & & & & 434 & & & & 445 & & & & 774 & & & \\
\hline R-squared & 0.234 & & & & 0.206 & & & & 0.242 & & & & 0.260 & & & & 0.233 & & & \\
\hline
\end{tabular}


Table 6. Benefit from Soft Information Production (All Firms)

(Benefit from relationship $)=f($ Accumulation of soft information, Bank type dummies, Access to hard information, Fir and entrepreneur control variables, Regional and bank controls).

This table presents Probit or Ordered Logit estimation results for the presence/absence of benefits from strong bankborrower relationships. The dependent variable in each panel is a proxy for benefits from bank-borrower relationship, which are described in Panel (C) of Table 1: TIGHT (dummy: financial condition being tight) in panel (A), EASY (dummy: financial condition being easy) in panel (B), STABLE (rating of the main bank with respect to stable provision of funds) in panel (C), and INEXPENSIVE (rating of the main bank with respect to inexpensive provision of funds) in panel (D). The main independent variable is a proxy for soft information accumulation, SOFT. ${ }^{* *},{ }^{* *}$, or $*$ means that the coefficient is statistically significant at a $1 \%, 5 \%$, or $10 \%$ level.

\begin{tabular}{|c|c|c|c|c|c|c|c|c|c|}
\hline \multirow{2}{*}{\multicolumn{2}{|c|}{ Variable }} & \multicolumn{4}{|c|}{$\begin{array}{l}\text { (A) TIGHT regression } \\
\text { (Probit, marginal effects) }\end{array}$} & \multicolumn{4}{|c|}{$\begin{array}{l}\text { (B) EASY regression } \\
\text { (Probit, marginal effects) }\end{array}$} \\
\hline & & \multirow{2}{*}{\begin{tabular}{|c|} 
Coefficient \\
-0.0025
\end{tabular}} & \multirow{2}{*}{\multicolumn{2}{|c|}{$\begin{array}{c}\text { Std. Error } \\
0.0074\end{array}$}} & \multirow{2}{*}{$\frac{\text { Prob. }}{0.737}$} & \multirow{2}{*}{\multicolumn{2}{|c|}{$\begin{array}{c}\text { Coefficient } \\
0.0080\end{array}$}} & \multirow{2}{*}{$\begin{array}{c}\text { Std. Error } \\
0.0100\end{array}$} & \multirow{2}{*}{$\frac{\text { Prob. }}{0.426}$} \\
\hline Soft information & SOFT & & & & & & & & \\
\hline \multirow{2}{*}{$\begin{array}{l}\text { Bank type } \\
\text { dummies }\end{array}$} & REGIONAL & 0.0349 & & 0.0389 & 0.352 & -0.0521 & & 0.0471 & 0.275 \\
\hline & UNION & 0.1592 & $* * *$ & 0.0445 & 0.000 & -0.0882 & $*$ & 0.0473 & 0.070 \\
\hline Access to hard info & AUDIT & 0.0439 & & 0.0442 & 0.295 & -0.0075 & & 0.0544 & 0.891 \\
\hline \multirow{20}{*}{$\begin{array}{l}\text { Firm and } \\
\text { entrepreneur } \\
\text { control variables }\end{array}$} & LOG(ASSET) & -0.0104 & & 0.0162 & 0.522 & 0.0846 & $* * *$ & 0.0221 & 0.000 \\
\hline & PERFORMANCE_LP & 0.1510 & $* * *$ & 0.0531 & 0.001 & -0.0998 & $*$ & 0.0561 & 0.088 \\
\hline & PERFORMANCE_PL & 0.0713 & & 0.0582 & 0.181 & -0.0994 & & 0.0671 & 0.157 \\
\hline & PERFORMANCE_LL & 0.3298 & $* * *$ & 0.0749 & 0.000 & -0.1931 & $* *$ & 0.0654 & 0.010 \\
\hline & DIVIDEND & -0.1673 & $* * *$ & 0.0277 & 0.000 & 0.1750 & $* * *$ & 0.0375 & 0.000 \\
\hline & FIRMAGE & 0.0000 & & 0.0006 & 0.949 & -0.0003 & & 0.0008 & 0.741 \\
\hline & LOG(EMPLOYEE) & 0.0034 & & 0.0202 & 0.868 & -0.0701 & $* *$ & 0.0273 & 0.010 \\
\hline & LISTED & (NA) & & & & 0.1869 & & 0.1892 & 0.333 \\
\hline & HOMEOWNER & -0.0678 & & 0.0686 & 0.282 & 0.0439 & & 0.0719 & 0.548 \\
\hline & CEOAGE & 0.0011 & & 0.0014 & 0.423 & 0.0020 & & 0.0017 & 0.260 \\
\hline & OSAKA & -0.0212 & & 0.0349 & 0.546 & -0.0051 & & 0.0466 & 0.912 \\
\hline & KOBE & -0.0038 & & 0.0475 & 0.936 & -0.0276 & & 0.0638 & 0.667 \\
\hline & KYOTO & -0.0264 & & 0.0386 & 0.511 & 0.0064 & & 0.0549 & 0.907 \\
\hline & CONST & 0.0504 & & 0.0635 & 0.399 & -0.1944 & $* * *$ & 0.0647 & 0.007 \\
\hline & MANUFAC & -0.0128 & & 0.0478 & 0.790 & -0.0427 & & 0.0636 & 0.503 \\
\hline & WHOLE & -0.0384 & & 0.0499 & 0.462 & -0.0773 & & 0.0690 & 0.271 \\
\hline & RETAIL & 0.0016 & & 0.0694 & 0.982 & -0.0645 & & 0.0953 & 0.510 \\
\hline & REALEST & -0.1249 & & 0.0584 & 0.214 & -0.0312 & & 0.1494 & 0.836 \\
\hline & RESTAU_HOTEL & -0.1175 & & 0.0681 & 0.287 & -0.0491 & & 0.1689 & 0.776 \\
\hline & SERVICES & 0.0061 & & 0.0591 & 0.918 & -0.0711 & & 0.0773 & 0.370 \\
\hline \multirow{2}{*}{$\begin{array}{l}\text { Regional and bank } \\
\text { controls }\end{array}$} & VISITINC_OTHER & -0.0058 & & 0.0270 & 0.831 & 0.0828 & $* *$ & 0.0348 & 0.019 \\
\hline & BRANCHR & 0.0022 & & 0.0038 & 0.563 & -0.0033 & & 0.0049 & 0.495 \\
\hline \multicolumn{2}{|c|}{ Number of observations } & \multicolumn{4}{|l|}{931} & \multicolumn{4}{|l|}{940} \\
\hline & & (C) $\mathrm{S}$ & $\begin{array}{l}\text { TAB } \\
\text { Orde }\end{array}$ & $\begin{array}{l}\text { 3LE regress } \\
\text { ered logit) }\end{array}$ & & (D) INEX & $\begin{array}{l}\text { XPEN } \\
\text { (Order }\end{array}$ & $\begin{array}{l}\text { NSIVE regi } \\
\text { ered logit) }\end{array}$ & sion \\
\hline & Variable & Coefficient & & Std. Error & Prob. & Coefficient & & Std. Error & Prob. \\
\hline Soft information & SOFT & 0.8454 & $* * *$ & 0.0490 & 0.000 & 0.6242 & $* * *$ & 0.0419 & 0.000 \\
\hline Bank type & REGIONAL & 0.7514 & $* * *$ & 0.1905 & 0.000 & 0.1639 & & 0.1770 & 0.354 \\
\hline dummies & UNION & 0.5893 & $* * *$ & 0.1948 & 0.002 & 0.1226 & & 0.1881 & 0.515 \\
\hline Access to hard info & AUDIT & 0.1920 & & 0.2054 & 0.350 & -0.0677 & & 0.1995 & 0.734 \\
\hline Firm and & LOG(ASSET) & 0.0366 & & 0.0814 & 0.653 & -0.1359 & $*$ & 0.0779 & 0.081 \\
\hline entrepreneur & PERFORMANCE_DS & -0.5709 & $* *$ & 0.2283 & 0.012 & -0.0680 & & 0.2206 & 0.758 \\
\hline control variables & PERFORMANCE_SD & -0.1124 & & 0.2758 & 0.684 & 0.1980 & & 0.2581 & 0.443 \\
\hline & PERFORMANCE_DD & -0.4973 & $*$ & 0.2845 & 0.080 & 0.0245 & & 0.2714 & 0.928 \\
\hline & DIVIDEND & 0.3714 & $* *$ & 0.1506 & 0.014 & 0.5423 & $* * *$ & 0.1422 & 0.000 \\
\hline & FIRMAGE & 0.0030 & & 0.0030 & 0.322 & -0.0004 & & 0.0028 & 0.896 \\
\hline & LOG(EMPLOYEE) & 0.0737 & & 0.1009 & 0.465 & 0.0351 & & 0.0959 & 0.714 \\
\hline & LISTED & -0.4464 & & 0.6641 & 0.501 & 0.2988 & & 0.6437 & 0.643 \\
\hline & HOMEOWNER & -0.1058 & & 0.2971 & 0.722 & -0.7325 & $* * *$ & 0.2789 & 0.009 \\
\hline & CEOAGE & -0.0073 & & 0.0068 & 0.284 & -0.0023 & & 0.0065 & 0.724 \\
\hline & OSAKA & 0.3515 & $*$ & 0.1812 & 0.052 & 0.3540 & $* *$ & 0.1719 & 0.039 \\
\hline & KOBE & 0.2661 & & 0.2441 & 0.276 & 0.2267 & & 0.2323 & 0.329 \\
\hline & KYOTO & -0.3453 & & 0.2112 & 0.102 & -0.1215 & & 0.1996 & 0.543 \\
\hline & CONST & -0.0350 & & 0.2858 & 0.902 & -0.1580 & & 0.2762 & 0.567 \\
\hline & MANUFAC & 0.7495 & $* * *$ & 0.2453 & 0.002 & 0.2924 & & 0.2305 & 0.205 \\
\hline & WHOLE & 0.8782 & $* * *$ & 0.2738 & 0.001 & 0.2945 & & 0.2586 & 0.255 \\
\hline & RETAIL & 0.5559 & & 0.3656 & 0.128 & -0.3150 & & 0.3536 & 0.373 \\
\hline & REALEST & 0.0759 & & 0.6265 & 0.904 & -0.8516 & & 0.5426 & 0.117 \\
\hline & RESTAU_HOTEL & 0.8918 & & 0.6615 & 0.178 & -0.5018 & & 0.6574 & 0.445 \\
\hline & SERVICES & 0.5423 & $*$ & 0.3062 & 0.077 & 0.1280 & & 0.2870 & 0.656 \\
\hline Regional and bank & VISITINC_OTHER & -0.0301 & & 0.1360 & 0.825 & -0.0418 & & 0.1291 & 0.746 \\
\hline controls & BRANCHR & 0.0071 & & 0.0189 & 0.706 & -0.0043 & & 0.0175 & 0.806 \\
\hline Number o & observations & 945 & & & & 943 & & & \\
\hline
\end{tabular}


Table 7. Benefit from Soft Information Production (Poor-Performing Firms Only)

This table presents the Probit regression results, where the dependent variables and the independent variables are the same as, respectivelly, those of the TIGHT regression and the EASY regression in Table 6. In this analysis, we confine the sample to firms that lost money in the previous year. ${ }^{* *},{ }^{* *}$, or $*$ means that the coefficient is statistically significant at a $1 \%, 5 \%$, or $10 \%$ level.

\begin{tabular}{|c|c|c|c|c|c|c|c|c|c|}
\hline & & \multicolumn{4}{|c|}{$\begin{array}{l}\text { (A) TIGHT regression } \\
\text { (Probit, marginal effects) }\end{array}$} & \multicolumn{4}{|c|}{$\begin{array}{c}\text { (B) EASY regression } \\
\text { (Probit, marginal effects) }\end{array}$} \\
\hline \multicolumn{2}{|c|}{ Variable } & Coefficient & & Std. Error & Prob. & Coefficient & & Std. Error & Prob. \\
\hline Soft information & SOFT & -0.1049 & $* * *$ & 0.0365 & 0.004 & 0.0673 & $* * *$ & 0.0249 & 0.007 \\
\hline \multirow{2}{*}{ Bank type dummies } & REGIONAL & 0.2282 & & 0.1465 & 0.123 & -0.0827 & & 0.0643 & 0.259 \\
\hline & UNION & 0.4868 & *** & 0.1471 & 0.006 & -0.1054 & & 0.0635 & 0.185 \\
\hline Access to hard info & AUDIT & -0.2342 & & 0.1394 & 0.150 & 0.1128 & & 0.1301 & 0.305 \\
\hline \multirow{18}{*}{$\begin{array}{l}\text { Firm and } \\
\text { entrepreneur control } \\
\text { variables }\end{array}$} & LOG(ASSET) & -0.0411 & & 0.0727 & 0.573 & 0.0898 & * & 0.0520 & 0.064 \\
\hline & PERFORMANCE L & -0.3684 & $* * *$ & 0.1103 & 0.002 & 0.0819 & & 0.0751 & 0.286 \\
\hline & DIVIDEND & -0.4719 & $* * *$ & 0.0672 & 0.001 & 0.5544 & $* * *$ & 0.1727 & 0.001 \\
\hline & FIRMAGE & -0.0017 & & 0.0026 & 0.507 & 0.0021 & & 0.0015 & 0.147 \\
\hline & LOG(EMPLOYEE) & 0.1522 & & 0.0973 & 0.120 & -0.1246 & * & 0.0716 & 0.062 \\
\hline & LISTED & (NA) & & & & -0.1139 & & 0.0535 & 0.114 \\
\hline & HOMEOWNER & -0.1214 & & 0.3334 & 0.712 & 0.0737 & & 0.1010 & 0.632 \\
\hline & CEOAGE & -0.0033 & & 0.0062 & 0.596 & 0.0026 & & 0.0038 & 0.499 \\
\hline & OSAKA & -0.0702 & & 0.1548 & 0.654 & -0.0370 & & 0.0905 & 0.695 \\
\hline & KOBE & 0.1025 & & 0.2054 & 0.613 & -0.1005 & & 0.0595 & 0.214 \\
\hline & KYOTO & 0.1896 & & 0.1707 & 0.266 & -0.0603 & & 0.0737 & 0.459 \\
\hline & CONST & 0.6293 & ** & 0.1375 & 0.010 & -0.1465 & ** & 0.0642 & 0.049 \\
\hline & MANUFAC & 0.5515 & $* *$ & 0.1994 & 0.021 & -0.1624 & & 0.0991 & 0.115 \\
\hline & WHOLE & 0.6660 & $* * *$ & 0.1502 & 0.007 & -0.2108 & ** & 0.0824 & 0.011 \\
\hline & RETAIL & 0.4966 & * & 0.2048 & 0.066 & -0.0948 & & 0.0714 & 0.332 \\
\hline & REALEST & (NA) & & & & (NA) & & & \\
\hline & RESTAU HOTEL & 0.3352 & & 0.4066 & 0.463 & (NA) & & & \\
\hline & SERVICES & 0.5470 & ** & 0.1615 & 0.021 & -0.1592 & & 0.0517 & 0.193 \\
\hline \multirow{3}{*}{$\begin{array}{l}\text { Regional and bank } \\
\text { controls }\end{array}$} & VISITINC_OTHER & 0.0163 & & 0.1120 & 0.884 & 0.0371 & & 0.0687 & 0.588 \\
\hline & BRANCHR & -0.0010 & & 0.0162 & 0.949 & 0.0118 & & 0.0089 & 0.155 \\
\hline & Number of observations & 118 & & & & 118 & & & \\
\hline
\end{tabular}

